\title{
PENGARUH MODEL PEMBELAJARAN ADVANCE ORGANIZER BERBASIS MIND MAP TERHADAP HASIL BELAJAR FISIKA SISWA PADA MATERI POKOK BESARAN DAN SATUAN DI KELAS X SMA
}

\author{
Karya Sinulingga dan Denny Munte \\ Jurusan Fisika, FMIPA Universitas Negeri Medan \\ Jl. Willem Iskandar, Psr V-Medan
}

\begin{abstract}
Abstrak. Penelitian ini bertujuan untuk mengetahui pengaruh model pembelajaran advance organizer berbasis mind map terhadap hasil belajar Fisika siswa. Populasi dalam penelitian ini adalah seluruh siswa kelas X SMA Negeri 5 Pematangsiantar semester I Tahun Pembelajaran 2012/2013 berjumlah 8 kelas. Pengambilan sampel dilakukan secara cluster random sampling, diambil 2 kelas yaitu kelas eksperimen diterapkan model pembelajaran advance organizer dan kelas kontrol diterapkan model pembelajaran konvensional. Berdasarkan hasil analisis data pretes diperoleh nilai rata-rata kelas eksperimen 37,25 dan kelas kontrol 36,63. Hasil uji beda nilai kedua kelas pada taraf signifikan $\alpha=0,05$ diperoleh $t_{\text {hitung }}=0,369$ dan $\mathrm{t}_{\text {tabel }}=1,991$. Dapat disimpulkan tidak terdapat perbedaan yang signifikan nilai pretes kedua kelas, artinya kedua kelas memiliki kemampuan awal yang sama. Selanjutnya dilakukan pembelajaran dengan model pembelajaran advance organizer berbasis mind map pada kelas eksperimen dan pembelajaran konvensional pada kelas kontrol. Setelah pembelajaran diberikan kemudian pada kedua kelas dilakukan postes. Untuk kelas eksperimen diperoleh nilai rata-rata 72,50 dan untuk kelas kontrol diperoleh 60,63 . Hasil pengujian hipotesis dengan taraf signifikan 0,05 diperoleh $t_{\text {hitung }}=$ 4,479 dan $t_{\text {tabel }}=1,666$. Karena $t_{\text {hitung }}>t_{\text {tabel }}$ maka hipotesis (Ha) diterima, sehingga dapat disimpulkan terdapat pengaruh model pembelajaran advance organizer berbasis mind map terhadap hasil belajar siswa pada materi pokok besaran Fisika dan satuannya di kelas $X$ semester I SMA Negeri 5 Pematangsiantar T.P 2012/2013.
\end{abstract}

Kata kunci: model pembelajaran, advance organizer, mind map, hasil belajar

\section{Pendahuluan}

Pendidikan merupakan suatu usaha sadar yang dilakukan untuk meningkatkan Sumber Daya Manusia (SDM) melalui kegiatan pengajaran. Dalam menghadapi era globalisasi, pendidikan harus mampu menciptakan sumber daya manusia yang tangguh. Oleh karena itu, perlu adanya peningkatan mutu pendidikan di Indonesia. Untuk dapat mewujudkan itu, ada banyak hal yang harus diperhatikan mulai dari pengadaan tenaga pendidik sampai usaha peningkatan mutu pendidikan. Salah satu upaya yang dilakukan pemerintah untuk meningkatkan pendidikan di Indonesia adalah dengan menetapkan Kurikulum Tingkat Satuan Pendidikan (KTSP). Pengembangan Kurikulum Tingkat Satuan Pendidikan (KTSP) perlu didukung oleh iklim pembelajaran yang kondusif bagi terciptanya suasana yang aman, nyaman dan tertib, sehingga proses pembelajaran dapat berlang- 
sung dengan menyenangkan (enjoyable learning). Iklim yang demikian akan mendorong terwujudnya proses pembelajaran lebih menekankan pada belajar mengetahui (learning to know), belajar berkarya (learning to do), belajar menjadi diri sendiri (learning to be), dan belajar hidup bersama (learning to live together). Suasana tersebut akan memupuk kemandirian dan berkurangnya ketergantungan di kalangan warga sekolah, bersifat adaptif, dan proaktif serta memiliki jiwa kewirausahaan tinggi (ulet, inovatif, dan berani mengambil resiko), tidak saja bagi peserta didik, tetapi juga guru dan pimpinannya (Mulyasa, 2006).

Kenyataannya di lapangan menunjukkan bahwa untuk mencapai idealisme seperti kondisi di atas, lembaga pendidikan dihadapkan pada berbagai permasalahan menyangkut diri siswa, pengajar, maupun fasilitas pembelajaran. Permasalahan-permasalahan tersebut juga timbul pada materi pelajaran Fisika. Fisika merupakan ilmu yang termasuk rumpun IPA, oleh karena itu Fisika mempunyai karakteristik sama dengan IPA. Karakteristik tersebut adalah objek ilmu Fisika, cara memperoleh serta kegunaannya. Dalam pembelajaran Fisika di SMA/MA terdapat dua hal yang berkaitan dengan Fisika yang tidak terpisahkan, yaitu Fisika sebagai produk (berupa fakta, konsep, prinsip, hukum, dan teori) dan Fisika sebagai proses (kerja ilmiah). Karena itu pelajaran Fisika adalah pelajaran yang mengajarkan berbagai pengetahuan yang dapat mengembangkan daya nalar, analisa sehingga hampir semua persoalan yang berkaitan dengan alam dapat dimengerti. Berdasarkan hasil studi pendahuluan yang peneliti lakukan di SMA Negeri 5 Pematangsiantar dengan adanya Program Pengalaman Lapangan Terpadu (PPLT), diperoleh data hasil belajar Fisika siswa yang dicapai pada umumnya masih rendah yaitu nilai rata-rata 50 sedangkan Kriteria Ketuntasan Minimal (KKM) yang akan dicapai adalah 65. Sehingga dapat dikatakan nilai rata-rata siswa tidak mencapai kriteria ketuntasan minimal yang diharapkan.

Rendahnya hasil belajar ini menunjukkan siswa mengalami kesulitan belajar. Salah satu keadaan siswa yang perlu mendapat perhatian guru adalah kesulitan di dalam belajar. Kesulitan siswa untuk memahami konsep yang diajarkan dipengaruhi oleh beberapa faktor antara lain: pimpinan, guru, metode dan pendekatan yang digunakan oleh guru, dan latar belakang siswa itu sendiri. Berdasarkan wawancara dengan salah satu guru SMA Negeri 5 Pematangsiantar, guru Fisikanya masih menggunakan model pembelajaran konvensional. Metode pembelajaran yang lebih banyak digunakan adalah metode ceramah, tanya jawab, dan penugasan. Model pembelajaran ini lebih banyak berpusat pada guru, dimana komunikasi lebih banyak satu arah dari guru ke siswa menyebabkan siswa terpaku mendengar dan betul-betul membosankan, situasi pembelajaran diarahkan pada learning to know, dan permasalahan yang disampaikan cenderung bersifat akademik (book oriented) tidak mengacu pada masalahmasalah kontekstual yang dekat dengan kehidupan siswa sehingga pembelajaran Fisika menjadi kurang bermakna. Hal ini yang menyebabkan partisipasi siswa di dalam belajar Fisika rendah yang berdampak pada hasil belajar siswa yang rendah pula.

Ketidaktepatan pemilihan metode pengajaran yang dilakukan oleh guru menyebabkan pelajaran Fisika mendapat kesan kurang baik dari siswa. Penyajian materi Fisika yang kurang menarik dan membosankan, akhirnya terkesan angker, sulit dan menakutkan bagi siswa, akibatnya banyak siswa SMA yang kurang menguasai konsep-konsep dasar Fisika, sehingga siswa tersebut tidak tertarik lagi mempelajarinya. Masalah yang dihadapi guru Fisika di SMA/ MA selain rendahnya hasil belajar siswa juga kurangnya kreativitas siswa, sekalipun guru telah berusaha semaksimal mungkin untuk mengajar dengan baik. Fenomena ini menjadi petunjuk tingginya kompleksitas pembelajaran saat ini. Kreativitas sebagai kemampuan untuk menciptakan sesuatu yang baru, sebagai kemampuan untuk memberikan gagasan-gagasan baru yang dapat diterapkan dalam pemecahan masalah, atau sebagai kemampuan untuk melihat hubungan-hubungan baru antara unsur- 
unsur yang sudah ada sebelumnya (Munandar, 1999).

Dalam proses pembelajaran di sekolah, siswa juga kurang didorong untuk mengembangkan kemampuan berpikir. Proses pembelajaran di kelas diarahkan kepada kemampuan anak untuk menghafal informasi atau hanya dominan aspek kognitifnya saja. Pendidikan tidak diarahkan untuk mengembangkan dan membangun karakter serta potensi yang dimiliki. Dengan kata lain, proses pendidikan kita tidak diarahkan membentuk manusia cerdas, memiliki kemampuan memecahkan masalah hidup, serta tidak diarahkan untuk membentuk manusia kreatif dan inovatif. Berdasarkan masalah di atas salah satu upaya yang dilakukan untuk meningkat hasil belajar siswa dalam bidang studi Fisika diperlukan cara yang tepat untuk memotivasi siswa dan mengembangkan kreativitas serta sikap inovatif dari pendidiknya agar siswa mau belajar dan membuat siswa aktif dalam proses belajar. Adapun model pembelajaran yang dapat diterapkan adalah Advance Organizer.

Model pembelajaran Advance Organizer memiliki kelebihan yang digunakan untuk mengatasi kesulitan siswa, yaitu mengarahkan dan menolong siswa dalam menanamkan pengetahuan baru. Advance Organizer merupakan suatu pertolongan mental yang disajikan sebelum materi baru, yang digunakan untuk membantu siswa mengingat dan mengaitkan kembali pengetahuan lama dengan materi yang baru diajarkan. Untuk mempermudah siswa mengingat informasi lebih lama, mengembangkan pemahaman dan memperoleh pandangan baru dapat digunakan dengan bantuan peta pikiran (mind map). Peta pikiran (Mind Map) adalah sebuah sistem berpikir yang bekerja sesuai dengan cara kerja alami otak manusia dan mampu membuka dan memanfaatkan seluruh potensi dan kapasitasnya. Sistem ini mampu memberdayakan seluruh potensi, kapasitas, dan kemampuan otak manusia sehingga menjamin tingkat kreativitas dan kemampuan berpikir yang lebih tinggi bagi penggunanya (Windura, 2008).
Berdasarkan latar belakang masalah di atas, maka penelitian ini bertujuan untuk mengetahui pengaruh model pembelajaran advance organizer berbasis mind map terhadap hasil belajar siswa pada sub materi pokok Besaran dan Satuan sesudah pembelajaran dan untuk mengetahui aktivitas belajar siswa selama proses pembelajaran dengan model pembelajaran advance organizer berbasis mind map terhadap hasil belajar siswa pada sub materi pokok Besaran dan Satuan sesudah pembelajaran.

\section{Metode Penelitian}

Penelitian ini dilaksanakan di SMA Negeri 5 Pematangsiantar Kotamadya Pematangsiantar dan dilaksanakan pada semester ganjil Tahun Pembelajaran 2012/2013. Populasi dalam penelitian ini adalah seluruh siswa kelas $\mathrm{X}$ SMA Negeri 5 Pematangsiantar semester I Tahun Pembelajaran 2012/2013 yang berjumlah 8 kelas. Pengambilan sampel dilakukan secara cluster random sampling. Dari 8 kelas, yang menjadi sampel penelitian ini adalah 2 kelas yaitu kelas eksperimen diterapkan model pembelajaran advance organizer dan kelas kontrol diterapkan model pembelajaran konvensional.

Untuk melaksanakan penelitian ini, ditempuh langkah-langkah sebagai berikut:

1. Tahap persiapan

Kegiatan yang dilakukan dalam tahap ini meliputi persiapan-persiapan sehubungan dengan pelaksanaan penelitian.

2. Tahap pelaksanaan

Melaksanakan pretes, melakukan analisis data pretes, melakukan pengajaran pada kedua kelas yaitu (pada kelas eksperimen adalah pengajaran Fisika dengan menggunakan model pembelajaran advance organizer berbasis mind map, pada kelas kontrol adalah pengajaran Fisika dengan menggunakan model pembelajaran konvensional), melaksanakan postes, melakukan pengolahan data pretes dan postes, melakukan analisis data postes yaitu uji normalitas, uji homogenitas, uji t, pada kelas 
eksperiman dan kelas kontrol. Kemudian dilakukan uji hipotesis.

Bila data penelitian berdistribusi normal dan homogen maka untuk menguji hipotesis menggunakan uji $\mathrm{t}$ dengan rumus (Sudjana 2005), yaitu:

$$
t=\frac{\bar{X}_{1}-\bar{X}_{2}}{S \sqrt{\frac{1}{n_{1}}+\frac{1}{n_{2}}}}
$$

Dimana $S$ adalah varians gabungan yang dihitung dengan rumus:

$$
S^{2}=\frac{\left(n_{1}-1\right) S_{1}{ }^{2}+\left(n_{2}-1\right) S_{2}{ }^{2}}{n_{1}+n_{2}-2}
$$

Kriteria pengujiannya adalah: Terima $\mathrm{H}_{\mathrm{O}}$, jika $t<t_{1-\alpha}$ dimana $t_{1-\alpha}$ didapat dari daftar distribusi t dengan peluang $(1-\alpha)$ dan $\mathrm{dk}=\mathrm{n}_{1}+$ $\mathrm{n}_{2}-2$ dan $\alpha=0,05$. Untuk harga t lainnya $\mathrm{H}_{\mathrm{O}}$ ditolak.

\section{Hasil Penelitian dan Pembahasan Hasil Penelitian}

Sebelum dilakukannya penelitian, tes yang akan diberikan kepada sampel terlebih dahulu divalidkan kepada validator yaitu kepada dua orang dosen Fisika Unimed dan satu orang guru Fisika SMA Negeri 5 Pematangsiantar. Dari validasi isi tersebut didapatkan bahwa soal tersebut termasuk dalam kategori baik dan valid. Diproleh data berikut:

Tabel 1. Nilai Pretes Kelas Eksperimen

\begin{tabular}{|c|c|c|c|c|c|}
\hline \multicolumn{3}{|c|}{ Kelas Eksperimen } & \multicolumn{3}{|c|}{ Kelas Kontrol } \\
\hline Nilai & Frek. & $\begin{array}{c}\text { Rata- } \\
\text { rata }\end{array}$ & Nilai & Frek. & $\begin{array}{l}\text { Rata- } \\
\text { rata }\end{array}$ \\
\hline 25 & 5 & & 25 & 6 & \\
\hline 30 & 6 & & 30 & 7 & \\
\hline 35 & 7 & & 35 & 9 & \\
\hline 40 & 13 & 37,25 & 40 & 8 & 36,63 \\
\hline 45 & 6 & & 45 & 6 & \\
\hline 50 & 3 & & 50 & 4 & \\
\hline \multicolumn{2}{|c|}{ Jumlah $=40$} & & \multicolumn{2}{|c|}{ Jumlah $=40$} & \\
\hline
\end{tabular}
dan Kelas Kontrol
Tabel 2. Nilai Postes Kelas Eksperimen dan Kelas Kontrol

\begin{tabular}{|c|c|c|c|c|c|}
\hline \multicolumn{2}{|c|}{ Kelas Eksperimen } & \multicolumn{3}{c|}{ Kelas Kontrol } \\
\hline Nilai & Frek. & $\begin{array}{c}\text { Rata- } \\
\text { rata }\end{array}$ & Nilai & Frek. & $\begin{array}{c}\text { Rata- } \\
\text { rata }\end{array}$ \\
\hline 45 & 2 & & 40 & 2 & \\
50 & 2 & & 45 & 2 & \\
55 & 2 & & 50 & 6 & \\
60 & 3 & & 55 & 7 & \\
65 & 2 & 72,50 & 60 & 6 & 60,63 \\
70 & 6 & & 65 & 8 & \\
75 & 5 & & 70 & 2 & \\
80 & 9 & & 75 & 4 & \\
85 & 7 & & 80 & 1 & \\
90 & 2 & & 85 & 2 & \\
\hline \multicolumn{2}{|c|}{ Jumlah = 40 } & & \multicolumn{3}{|c|}{ Jumlah = 40 } \\
\hline
\end{tabular}

Tabel 3. Ringkasan Hasil Perhitungan Nilai

\begin{tabular}{|c|c|c|c|c|}
\hline \multirow[t]{2}{*}{ Hasil } & \multicolumn{2}{|c|}{$\begin{array}{c}\text { Kelas } \\
\text { Eksperimen }\end{array}$} & \multicolumn{2}{|c|}{ Kelas Kontrol } \\
\hline & $\begin{array}{l}\text { Nilai } \\
\text { Pretes }\end{array}$ & $\begin{array}{l}\text { Nilai } \\
\text { Postes }\end{array}$ & $\begin{array}{l}\text { Nilai } \\
\text { Pretes }\end{array}$ & $\begin{array}{l}\text { Nilai } \\
\text { Postes }\end{array}$ \\
\hline $\begin{array}{l}\text { Rata- } \\
\text { Rata }\end{array}$ & 37,25 & 72,5 & 36,63 & 60,63 \\
\hline $\begin{array}{l}\text { Standar } \\
\text { Deviasi }\end{array}$ & 7,24 & 12,40 & 7,79 & 11,28 \\
\hline Varians & 52,42 & 153,76 & 60,69 & 127,24 \\
\hline
\end{tabular}
Rata-Rata, Standar Deviasi, dan Varians

Setelah data memenuhi persyaratan homogenitas dan normalitas maka dilakukan pengujian hipotesis. Ringkasan perhitungan uji hipotesis kelas eksperimen dan kelas kontrol sebagai berikut:

\begin{tabular}{|c|c|c|c|c|}
\hline Data Kelas & $\begin{array}{c}\text { Nilai } \\
\text { Rata - } \\
\text { rata }\end{array}$ & $\mathrm{t}_{\text {hitung }}$ & $\mathrm{t}_{\text {tabel }}$ & Kesimpulan \\
\hline $\begin{array}{l}\text { Pretes } \\
\text { Eksperimen }\end{array}$ & 37,25 & \multirow{2}{*}{0,369} & \multirow{2}{*}{1,991} & \multirow{2}{*}{ Terima $\mathrm{H}_{0}$} \\
\hline $\begin{array}{l}\text { Pretes } \\
\text { Kontrol }\end{array}$ & 36,63 & & & \\
\hline $\begin{array}{l}\text { Postes } \\
\text { Eksperimen }\end{array}$ & 72,50 & \multirow{2}{*}{4,479} & \multirow{2}{*}{1,666} & \multirow{2}{*}{ Terima $\mathrm{H}_{\mathrm{a}}$} \\
\hline $\begin{array}{l}\text { Postes } \\
\text { Kontrol }\end{array}$ & 60,63 & & & \\
\hline
\end{tabular}

Tabel 4 Ringkasan Perhitungan Uji Hipotesis 


\section{Pembahasan}

Hasil penelitian menunjukkan adanya pengaruh penggunaan model pembelajaran advance organizer berbasis mind map. Hal ini dinyatakan dengan perbedaan hasil belajar siswa pada kelas eksperimen yang diajarkan dengan model pembelajaran advance organizer berbasis mind map memperoleh nilai rata-rata 72,50 dan kelas kontrol yang diajarkan dengan model pembelajaran konvensional memperoleh nilai rata-rata 60,63 .

Hasil tersebut diperoleh karena model pembelajaran advance organizer berbasis mind map dilakukan dengan 3 langkah penting. Pertama, penyajian advance organizer berbasis mind map . Pada langkah ini dilakukan dengan beberapa hal, yaitu mengklarifikasikan tujuan pembelajaran yang dapat membangun perhatian siswa dan menuntunya pada tujuan pembelajaran sehingga tercapai suatu cara belajar bermakna, penyajian organizer berupa kerangka konsep yang umum dan menyeluruh kemudian dilanjutkan dengan penyajian informasi yang lebih spesifik dengan tujuan untuk memperluas wawasan siswa dan mendorong siswa memberikan respon terhadap presentasi organizer. Kedua, penyajian materi pelajaran. Langkah kedua dikembangkan dalam bentuk diskusi dan siswa melakukan percobaan yang secara emosional menyebabkan siswa aktif, lebih semangat dan lebih antusias dalam memahami materi pelajaran serta mengarahkan siswa pada tujuan pembelajaran yang ditunjukan pada langkah pertama. Ketiga, penguatan pengolahan kognitif. Pada langkah ini siswa menjelaskan pengetahuan yang telah diperolehnya yaitu dengan mempresentasikan hasil diskusinya dan menghubungkan materi yang baru dengan pengalaman atau pengetahuan yang dimilikinya. Selain itu siswa diberikan pertanyaan-pertanyaan tentang asumsi atau pendapatnya yang berhubungan dengan materi pelajaran seperti contoh-contoh dan perbedaanperbedaan yang terdapat dalam aspek materi.

Namun demikian, dalam menerapkan model pembelajaran advance organizer berbasis mind map penulis menemukan kendala dalam penelitian ini antara lain, sulitnya untuk menjangkau setiap kelompok karena pengaturan posisi meja masing-masing kelompok yang kurang tepat, tidak semua kelompok dapat mempresentasikan hasil diskusinya karena waktu yang terbatas, dan adanya siswa yang kurang memperhatikan ketika materi pelajaran disampaikan, dan mengganggu temannya yang menyebabkan keributan.

Untuk mengatasi kendala tersebut dapat dilakukan antara lain, pertama, melakukan pengaturan posisi meja diskusi dengan cara 3 baris meja-kursi kelompok ke samping dan 2 baris meja-kursi kelompok ke belakang (menyesuaikan dengan bentuk ruangan kelas) yang tujuannya agar terdapat jarak antar kelompok sehingga mudah bergerak ke setiap meja kelompok siswa. Sebelumnya pengaturan posisi meja dan kursi beberapa kelompok berdekatan tanpa ada jarak. Kedua, menyesuaikan materi diskusi dengan alokasi waktu yang tersedia dengan cara mengurangi variasi penggunaan alat ukur ataupun pertanyaan yang berhubungan dengan aspek materi yang sama. Ketiga, menegur dan menasihati siswa yang kurang memperhatikan materi pelajaran dan yang mengganggu temannya, bahwa konsentrasi diperlukan agar materi pelajaran yang baru mudah dipahami dan diterapkan.

\section{Simpulan}

Berdasarkan hasil analisis yang dilakukan dapat disimpulkan:

1. Terdapat pengaruh model pembelajaran advance organizer berbasis mind map terhadap hasil belajar siswa pada sub materi pokok Besaran dan Satuan di Kelas X Semester I SMA Negeri 5 Pematangsiantar T.P.2012/2013. Hal ini dilihat dari rata-rata hasil belajar siswa pada kelas eksperimen yang menggunakan model pembelajaran advance organizer berbasis mind map adalah 72,50. Sedangkan rata-rata hasil belajar siswa pada kelas kontrol yang menggunakan model pembelajaran konvensional adalah 60,63 . 
2. Aktivitas belajar siswa selama proses pembelajaran dengan model pembelajaran advance organizer berbasis mind map pada sub materi pokok Besaran Fisika dan Satuannya di Kelas X Semester I SMA Negeri 5 Pematangsiantar T.P 2012/2013 secara keseluruhan baik.

\section{DAFTAR PUSTAKA}

Mulyasa, E. 2006. Implementasi Kurikulum Tingkat Satuan Pendidikan Kemandirian Guru dan Kepala Sekolah. Jakarta: Bumu Aksara.
Munandar, U. 1999. Pengembangan Kreativitas Anak Berbakat. Jakarta: Rineka Cipta.

Munandar, U. 1992. Mengembangkan Bakat dan Kreativitas Anak Sekolah Petunjuk

bagi Para Guru dan Orang Tua. Jakarta: Gramedia.

Sudjana. 2005. Metode Statistik. Bandung: Penerbit Tarsito.

Sudjana, N. 2002. Penilaian Hasil Proses Mengajar. Bandung: PT. Rosdakarya.

Windura, S. 2008. Mind Map for Business Effectiveness. Jakarta: Gramedia. 